\title{
Omologede Community Development Association and Flood Management in Ogolonto Community, Nigeria
}

\author{
${ }^{1}$ Michael I. Ogu , ${ }^{2}$ Oreofeoluwa Fadeyi \\ Department of Political Science and Public Administration Babcock University, Ogun State, Nigeria \\ Department of Political Science and Public Administration Babcock University, Ogun State, Nigeria
}

\begin{abstract}
How effective are Community Development Associations in curbing the challenge of flood in Nigeria? This study investigated the efforts of Community Development Associations, which have been arguably classified as a fourth tier of government, in flood management, using the Omologede Community Development Association as a case in point.

The study adopted the mixed research method; purposive sampling technique was used in gathering primary data, while secondary data were gathered from relevant journal articles, text books and other secondary sources.

The study concludes that community development associations can play more developmental roles in the community if given better attention by the government, and incorporated into the development process. It recommends an improved personal and environmental sanitation behavior from the indigenes in the community as well as improved flood management rules and regulation by the Community Development Association.
\end{abstract}

Key words: Community, Development, Community Development Association, Flood, Management Word Count: 136 words

\section{Introduction}

Development arguably has been the most and essentially sort after outcome among government and people. Even the day to day activities of government seem to be focused on how to bring about better standards of living, increase per-capital income and provide an increase in other indices of development.

Community development activities date back to early years of civilization, even before the advent of the colonial administration, when people had at different times, organized themselves into groups and had used communal resources to provide physical improvement and functional facilities in their communities. Since the early years of human societies, communities have earnestly sought out ways to improve their standards of living through self-help efforts otherwise known as community development activities under the umbrella of community development association.

Community development is a demonstration of people's capacity and willingness to participate, on their own initiative, in the tasks of identifying and prioritizing community needs (e.g. socioeconomic, political and environmental); planning and implementing programmes aimed at meeting the needs; and improving their living conditions with or without external assistance (Peterman, 2000; Musa, 2005).

Community development is usually carried out under the umbrella of Community Development Associations which is the coming together of people living within a given locality or community with the sole aim of identifying their felt needs and agreeing on the ways, means and moves towards the realization of such identified needs. They execute these plans, with a maximum reliance upon community resources and supplement these resources, when necessary with services and materials from the government (Amadike, 1989 and Olujide, 2005).

Flooding, on the other hand, is a phenomenon that increasingly has had devastating effects on human lives. The impact of flood is more pronounced in some areas due to rapid growth in population, poor governance, decaying infrastructure and lack of proper environmental planning and management. Flooding is also exacerbated by climate change and inadequate preparedness. However, flooding in most Nigerian cities is a major environmental challenge that has continued to defy solution as more people are rendered vulnerable to the associated hazards. The implications of recent flooding in Nigerian cities include among others; loss of life and properties, spread of diseases, deformed lives, assets and infrastructure, among others (Odufuwa., et. al; 2012).

In Nigeria, though not leading in terms of claiming lives, flood affects and displaces more people than any other disaster; it also serves more damage to properties. In Nigeria, flood disaster has been perilous to people, communities and institutions. The country has faced unprecedented flood disaster resulting in loss of lives and property running into billions of naira.

Flood is very problematic, and its devastating effects can be categorized into structural, economic, and health related effects (Adedeji, 2008). 
Flood, which is described as a body of water which moves over and above an area of land which is not normally submerged is a common environmental problem in Nigeria. It could also be seen as the inundation of an area not normally covered with water, through a temporary rise in levels of stream, river, lake or sea. Like drought, flood is usually described as disaster (Oyebande, 1975).

The problems created by this natural event are worsened by the negative interaction of humans with the environment, and they often result in structural and erosional damage, loss of lives and property, disruption of socioeconomic activities, destruction of agricultural land, contamination of water and the environment in general as well as displacement of human beings.

Despite the responses and actions taken by governments and other agencies to mitigate flood and the damage it brings upon lives and properties in several human communities, flood has remained a major threat to the security of lives and properties of Nigerians. This study attempts to investigate what role Community Development Associations play in managing flood disasters, using the Omologede Community Development Association in Ogolonto area of Ikorodu, Lagos State as a case in point.

\section{Theoretical Framework}

This study adopted the systems approach in explaining the role of the Omologede Community Development Association in managing flood events in the study area.

A system is defined by Von Bertalanffy as "a set of elements standing in interaction"; in other words, a group of things which have something in common. This includes any grouping with any sort of relationship; a collection of people, a forest, the planets, rabbits on a hill-side, a pile of rocks, or anything else if it is possible to identify a group of things, this cluster can be seen as a "system."

Community Development Association (CDA) is a system that exists within the larger community system, hence the proper functioning of such associations tells a great deal on the development of the community at large.

Scholars argue that equilibrium must be maintained among various sub-systems in a social or political system, this is necessary to avoid stress and strains that can possibly lead to total collapse or breakdown of such social or political system. Hence, all sub-systems within a larger system ought to work optimally for the wholesome development of system.

Major scholars of the system approach include, David Easton who, arguably, first attempted the introduction of system theory into the field of Political science by his classic 1953 essay titled The political system: An inquiry into the State of Political Science; published in New York, by Alfred A. Knopf. Thomas Hobbes', Leviathan, among others, is also worthy of mention.

\section{History Of Omologede Village}

In an interview with the Chairman of the Omologede Community Development Association, the history of Omolodege village is reported thus: Omologede is a parcel of land situated at Mologede village Ogolonto near Ikorodu Township with a population of about five thousand people. It is the property of the entire Lenuwa Osholonge family of No 14, Idewu - Olu Street, Lagos State.

The Osholonge ancestor - Chief Lenuwa Osholonge acquired title of the parcel of the land by right of purchase from Balogun Jaiyesimi for himself and on behalf of Osholonge Family in the year 1896. By virtue of the aforesaid sale, Chief Lenuwa Osholonge was installed into physical possession of the large parcel of land by Balogun Jaiyesimi and other members of Balogun Jaiyesimi Family in the presence of all witnesses. Chief Lenuwa Osholonge exercised total act of dominion and control over the said land until death; he cultivated the farmland, planted, cocoa, kola nuts, oranges and palm trees. Chief Lenuwa Osholonge had boundary with men like Mr. Animashaun, Ojebiyi (Baba Onimole) and other who had always been on their farmlands.

The said Chief Lenuwa died in 1903 and left several surviving children including Aborisade, Aye Lasisi, Adamo, Olajide ,Asamotu Olayinka who succeeded him to the land by virture of customary rights of Lagos.

That Osholonge family had tenants on the land under the supervision of a tenant called Sanni. Sanni was later made the Baale of the village till his death. Laniyan, Morakinyo also became Baales after Sanni.

When the Federal Government was constructing the first Lagos to Ikorodu Motor road in 1951, the road passed through the said Osholonge Family land and the family claimed and received the sum of Seventy Pounds Fifteen Shillings and nine pence (75: 15: 9p) as compensation for a portion of their said family land situate along the access road acquire by the Federal Government. The remains of Osholonge family ancestors was exhumed from the access road to Ikorodu Lighter Terminal and reburied on another portion of the family Land. The Lagos State Government acquired a sizeable portion of the family land with an area of 17. 5 hectares for the establishment of the Government College, Ikorodu, for which compensation is yet to be paid by the Lagos state government. 
When the Land Use Act came into force on the 29th day of March, 1987, the Chief Lenuwa Osholonge Family were the persons lawfully occupying the larger portions of the land in accordance with customary law and accordingly the said Chief Lenuwa Osholonge Family became holders of the customary Right of Occupancy over the entire land.

\section{Omologede Community Development Association}

The Omologede Community Development Association is an association of community members in the Ogolonto village that is set up to meet the developmental challenges of the community, either through self-help methods or by collaboration with the government.

The Vision of the Omologede Community Development Association is listed below:

A. To ensure that each community member have sense of belonging.

B. B. To collaborate with all diverse communities for overall development.

C. C. To improve the lives of the entire neighborhood.

D. D. To meet the government at both State and Local levels to discuss the needs of the community.

E. E. To be a change agent of socialization and friendship.

F. F. To exchange ideas.

The Mission of the Omologede Community Development Association is also listed below:

A. To increase communities based amenities and support those in needs.

B. To increase Public safety through neighborhood input and support of community policing with the police service.

C. To address environmental issues and create inclusive environment.

D. To act as a resource and first stop for quality information.

E. To offer programmes and services based on residents needs and interest.

F. To create ability that will influence decisions that impact on individual and family.

\subsection{Organogram}

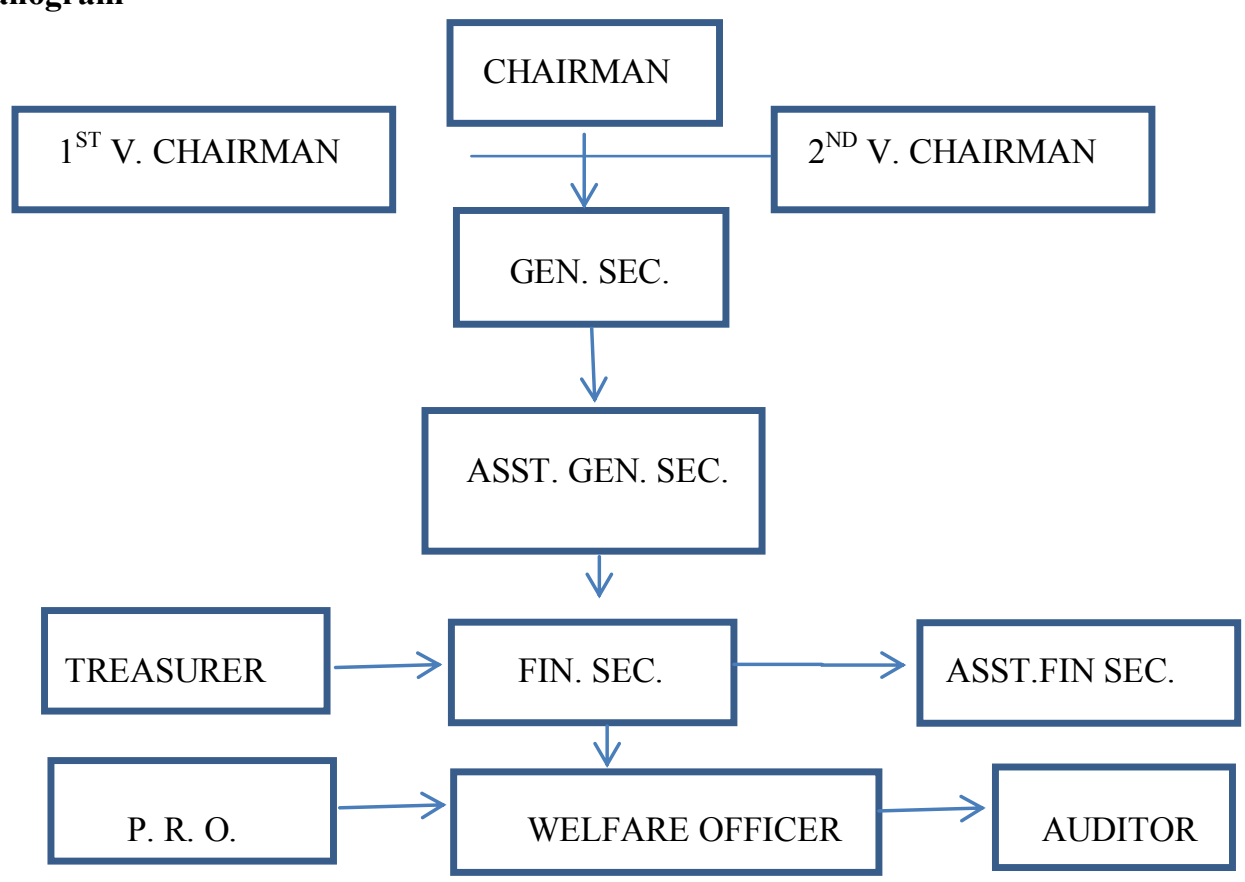

\section{Assessment Of Flooding In Nigeria}

Director-General of the National Emergency Management Agency (NEMA), Mr. Muhammed SaniSidi, has said Nigeria lost N2.6millin to the 2012 flood disaster. He asserts further that the disaster which resulted in 363 deaths, affected seven million people, displaced 2.3 million others and damaged 597,476 houses. According to Sani-Sidi, the report of the Comprehensive Post Disaster Needs Assessment conducted from November 2012 to March 2013, with the support of the World Bank and Global Facility for Disaster Reduction and Recovery, United Nations, Development partners and relevant Ministries, Departments and Agencies, put the estimated total value of infrastructure, physical and durable assets destroyed by flood at $\$ 9.6 \mathrm{bn}$. The total value of losses across all sectors of economic activity was estimated at $\$ 7.3 \mathrm{bn}$, putting the combined value of these damages and losses at $\$ 16.9 \mathrm{bn}$. 
Describing 2012 as a challenging year for the country, the NEMA boss said the incident provided a platform for the government and other stakeholders to converge on pending developmental issues and the need to take the requisite step to respond to flooding challenges. He added that;

"The flood was a classic case of how disasters can reverse development in a developing country like Nigeria. However, the calamities wrought by the 2012 floods offer for our country an important window of opportunity to address difficulties and long-standing development issues. It brought all stakeholders together as never before to address the consequences of the flood, plan to reduce the vulnerability of our people and increase their resilience".

Sani-Sidi, who commended the efforts with United Nations International Strategy for Disaster Reduction in engaging citizens on the post 2015 Hyogo Framework for Action, called for the inclusion of women and children in the implementation of the initiative.

The framework adopted by the World Conference on Disaster Reduction at Kobe, Hyogo, Japan in 2005 , provides an opportunity to "promote a strategic and systematic approach to reducing vulnerabilities".

He said the country had observed some gaps in the framework between the practice and principle of disaster risk reduction at the country level. According to him, nationwide consultations on the post-2015 Hyogo Framework at the Federal Capital Territory and the six geopolitical zones "give us the indication that the participation of women and children will be critical to the successful implementation of any framework on Disaster Risk Reduction (DRR) beyond 2015”.

\section{Omologede Community Development Association And Flood Management In Ogolonto}

In order to measure the effort of the Omologede Community Development Association in managing flood in Ogolonto community, a questionnaire was constructed to gather data from the population of study. Two hundred (200) questionnaires were randomly and purposively administered to the members of Ogolonto community, and one hundred and twenty (120) questionnaires; $40 \%$ were retrieved. The analysis of the data gathered is given below;

6.1 Analysis Of Respondents Bio-Data

Table 6.1.1 Sex of the respondents

\begin{tabular}{|c|c|c|}
\hline & Frequency & Percent \\
\hline Male & 79 & 65.8 \\
\hline Female & 41 & 34.2 \\
\hline Total & 120 & 100.0 \\
\hline
\end{tabular}

Source: Field Survey, March2014

Table 6.1.1 shows that the respondents comprised 79 males $(65.8 \%)$ and 41 females $(34.2 \%)$.

Table 6.1.2 Qualification of Respondents

\begin{tabular}{|l|r|r|}
\hline & Frequency & Percent \\
\hline O'Level & 48 & 40 \\
HND & 35 & 29.7 \\
B.Sc & 21 & 17.5 \\
M.Sc & 8 & 6.7 \\
Others & 8 & 6.7 \\
Total & 120 & 100.0 \\
\hline
\end{tabular}

Source: Field Survey, March 2014

From the table, 48(40\%) of the respondents are O'level holders, 35(29.7\%) HND, 21(17.5\%) B.sc, $8(6.7)$ M.sc and 8(6.7) have other qualification(s).

Table 6.1.3 Age Range of Respondent

\begin{tabular}{|l|r|r|}
\hline & Frequency & Percent \\
\hline Below 18 years & 26 & 21.7 \\
18-25 years & & 52 \\
26-30 years & 29 & 43.3 \\
31 years and above & 13 & 24.2 \\
Total & 120 & 10.8 \\
\hline
\end{tabular}

Source: Field Survey, March 2014 
From the above table 6.1.3, 26(21.7\%) of the respondents are below 18years, 52(43.3\%) are between the ages of $18-25$ years, $29(24.2 \%)$ are between the ages of 26-30years and $13(10.8 \%)$ are 31 years and above.

Table 6.1.4 Marital Status of Respondent

\begin{tabular}{|c|c|c|}
\hline & Frequency & Percent \\
\hline Single & 54 & 45 \\
\hline Married & 63 & 52.5 \\
\hline Others & 3 & 2.5 \\
\hline Total & 120 & 100.0 \\
\hline
\end{tabular}

Source: Field Survey, March2014

Table 6.1.4 shows the marital status of respondents thus; 54(45\%) are single, 63(52.5\%) are married and $3(2.5 \%)$ are neither married nor single.

Table 6.1.5 Community status of respondent

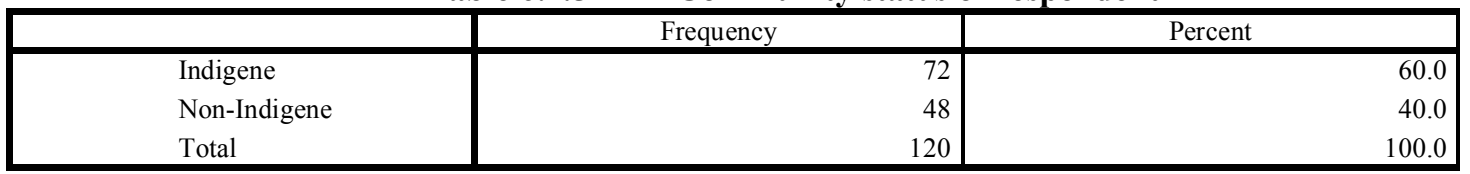

Source: Field Survey, March 2014

From the table, $72(60.0 \%)$ are indigene while $48(40.0 \%)$ are non-indigene.

6.2 Analysis Of Research Question

Table 6.2.1 Omologede CDA is a well-known association among indigenes of Ogolonto community

\begin{tabular}{|l|r|r|}
\hline & Frequency & Percent \\
\hline Very Highly Agree & 84 & 70 \\
Highly Agree & 22 & 18.4 \\
Very Highly Disagree & 4 & 3.3 \\
Highly Disagree & 6 & 5 \\
Undecided & 4 & 3.3 \\
Total & 120 & 100.0 \\
\hline
\end{tabular}

Source: Field Survey, March2014

Table 6.2.1 shows that $84(70 \%)$ of the respondents 'very highly agree' that the Omologede Community Development Association is a well-known association among indigenes of Ogolonto community, 22(18.4\%) 'highly agree', 4(3.3\%) 'very highly disagree', 6(5\%) 'highly disagree' and 4(3.3\%) were undecided.

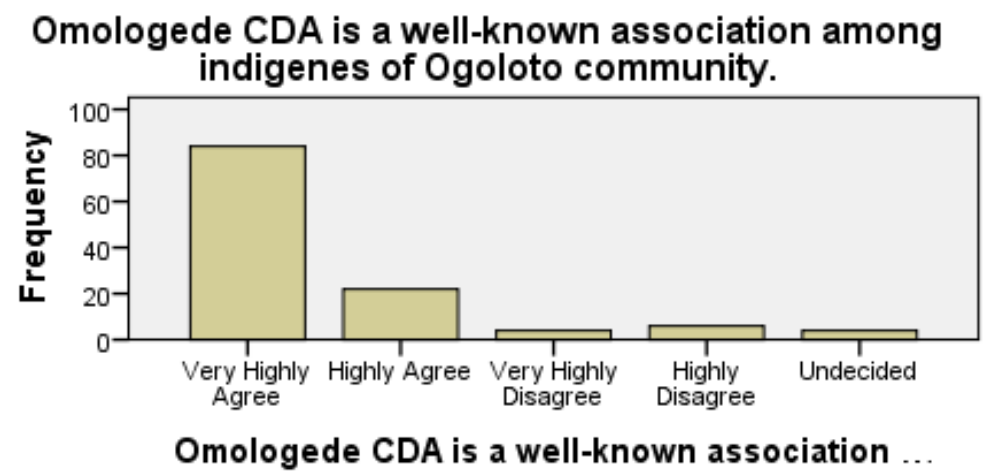

Source: SPSS 21 Analysis, Researcher's computation, March 2014 
Table 6.2.2 Membership of Omologede CDA is opened to all interested individuals

\begin{tabular}{|l|r|r|}
\hline & Frequency & Percent \\
\hline Very Highly Agree & 60 & \\
Highly Agree & 48 & \\
Very Highly Disagree & 7 & \\
Highly Disagree & 3 & \\
Undecided & 2 & 5.8 \\
Total & 120 & 2.5 \\
\hline
\end{tabular}

Source: Field Survey, March 2014

From table $6.2 .2,60(50 \%)$ of the respondents 'very highly agree' that the membership of Omologede Community Development Association is opened to all interested individual, 48(40\%) 'highly agree', 7(5.8\%) 'very highly disagree', 3(2.5\%) 'highly disagree' and 2(1.7\%) were undecided.

\section{Membership of Omolgede CDA is opened to all} interested individuals.

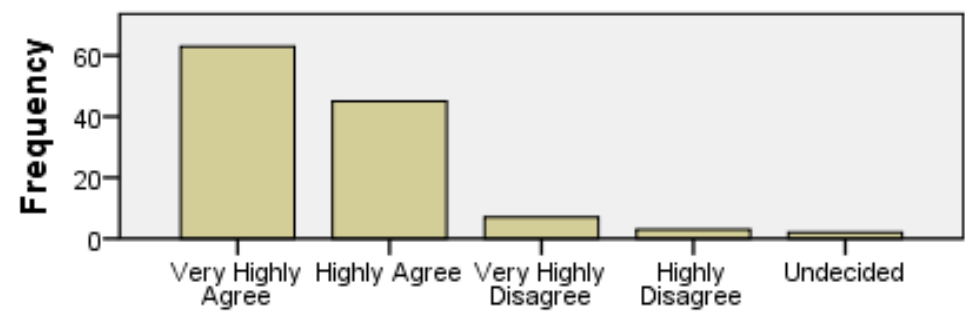

\section{Membership of Omolgede CDA is opened to all} interested individuals.

Source: SPSS 21 Analysis, Researcher's computation, 2014

Table 6.2.3 Omologede CDA is a vibrant unit of Ogolonto community

\begin{tabular}{|l|r|r|}
\hline & Frequency & Percent \\
\hline Very Highly Agree & 67 & 55.8 \\
Highly Agree & 21 & 17.5 \\
Very Highly Disagree & 25 & \\
Highly Disagree & 7 & 20.9 \\
Total & 120 & 5.8 \\
\hline
\end{tabular}

Source: Field Survey, March2014

From table 6.2.3 above, 67(55.8\%) of the respondents 'very highly agree' that Omologede Community Development Association is a vibrant unit of the Ogolonto community, 21(17.5\%) 'highly agree', 25(20.9\%) 'very highly disagree' and 7(5.8.\%) 'highly disagree'.

\section{Omologede CDA is a vibrant unit of the ogolonto} community.

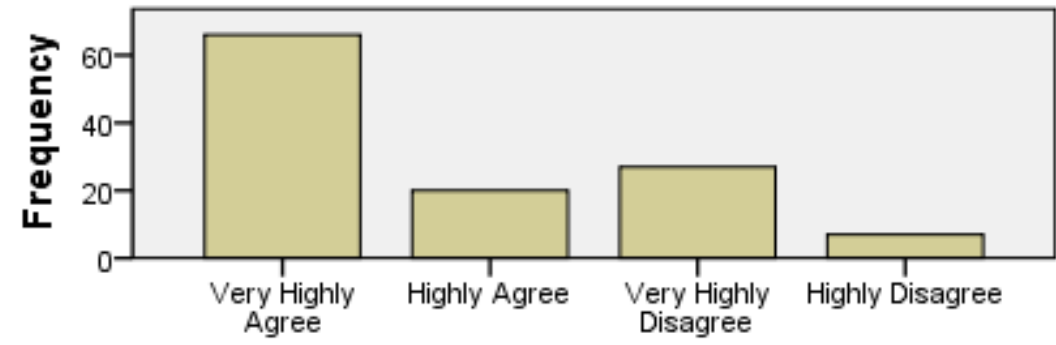

Omologede CDA is a vibrant unit of the ...

Source: SPSS 21 Analysis, Researcher's computation, 2014 
Omologede Community Development Association and Flood Management in Ogolonto Community,

Table 6.2.4 Omologede CDA is transparent and associated to the indigenes and leadership of Ogolonto community

\begin{tabular}{|l|r|r|}
\hline & Frequency & \multicolumn{2}{|c|}{ Percent } \\
\hline Very Highly Agree & 66 & 55 \\
Highly Agree & 24 & 20 \\
Very Highly Disagree & 14 & 20 \\
Highly Disagree & 6 & 5 \\
Undecided & 10 & 8.3 \\
Total & 120 & 100.0 \\
\hline
\end{tabular}

Source: Field Survey, March2014

Table 6.2.4 shows that, 66(55\%) of the respondents 'very highly agree' that the Omologede Community Development Association is transparent and associable to the indigenes and leadership of Omologede community, 24(20\%) 'highly agree', 18(15\%) 'very highly disagree', 6(5\%) 'highly disagree' and $10(8.3 \%)$ were undecided.

\section{Omologede CDA is transparent and associable to the indigenes and leadership of Ogolonto community.}

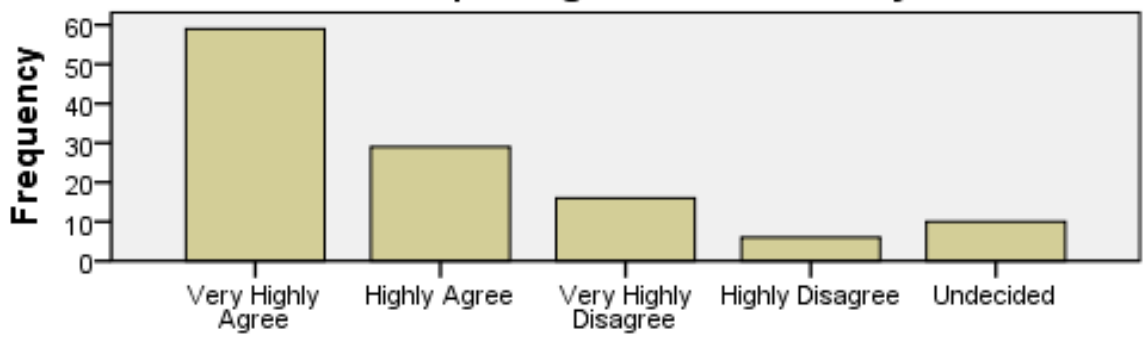

Omologede CDA is transparent and associable to the indigenes and leadership of Ogolonto community.

Source: SPSS 21 Analysis, Researcher's computation, 2014

Table 6.2.5 Omologede CDA always advocates the interest of Ogolonto people before government.

\begin{tabular}{|l|r|r|}
\hline & Frequency & Percent \\
\hline Very Highly Agree & 67 & 55.8 \\
Highly Agree & 25 & 20.8 \\
Very Highly Disagree & 10 & 8.5 \\
Highly Disagree & 9 & 7.5 \\
Undecided & 9 & 7.5 \\
Total & 120 & 100.0 \\
\hline
\end{tabular}

Source: Field Survey, March2014

From table $6.2 .5,67(55.8 \%)$ of the respondents 'very highly agree' that the Omologede Community Development Association always advocate the interest of Ogolonto people before the government, 25(20.8\%) 'highly agree', 10(8.3\%) 'very highly disagree', 9(7.5\%) 'highly disagree' and 9(7.5\%) were undecided.

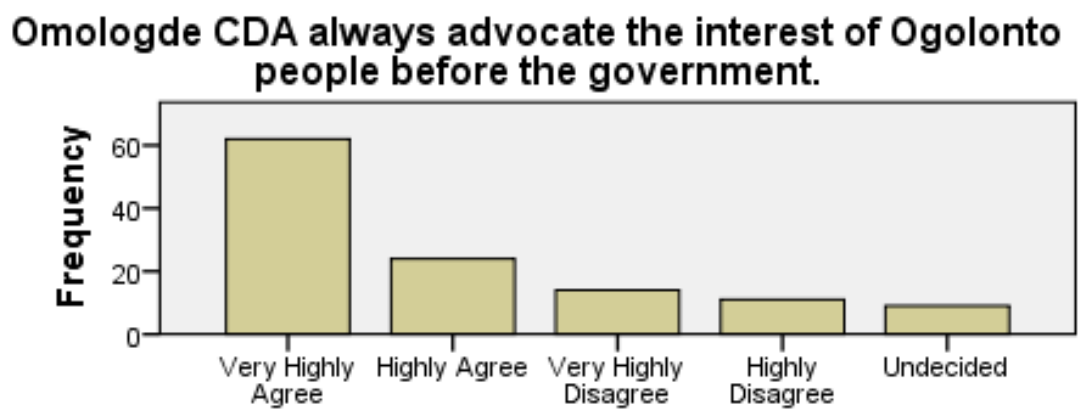

Omologde CDA always advocate the interest of ...

Source: SPSS 21 Analysis, Researcher's computation, 2014 
Omologede Community Development Association and Flood Management in Ogolonto Community,

Table 6.2.6 Flood is a major development challenge in Ogolonto community

\begin{tabular}{|l|r|r|}
\hline & Frequency & Percent \\
\hline Very Highly Agree & 86 & 71.2 \\
Highly Agree & 10 & 8.3 \\
Very Highly Disagree & 5 & 4.7 \\
Highly Disagree & 13 & 10.8 \\
Undecided & 6 & 5 \\
Total & 120 & 100.0 \\
\hline
\end{tabular}

Source: Field Survey, March2014

From table 6.2.6, 86(71.2\%) of the respondents 'very highly agree' that flood is a major challenge in Ogolonto community, $10(8.3 \%)$ 'highly agree', $5(4.7 \%)$ 'very highly disagree', $13(10.8 \%)$ 'highly disagree' and $6(5 \%)$ were undecided.

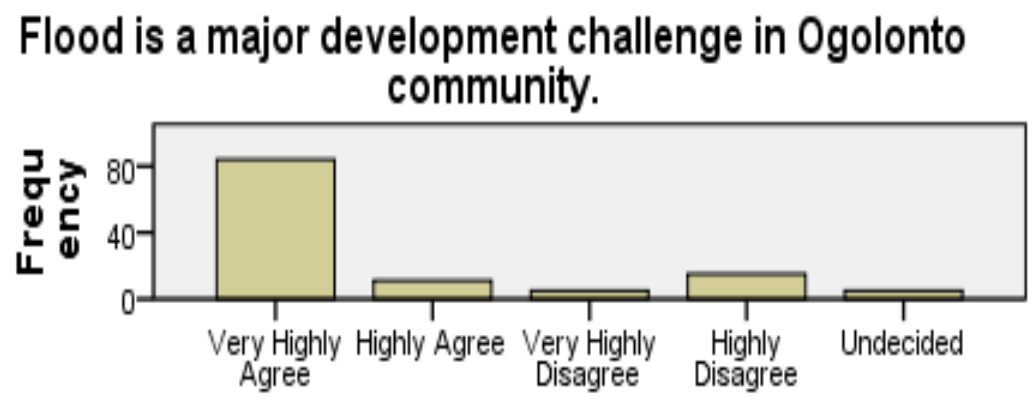

Flood is a major development challenge in ...

Source: SPSS 21 Analysis, Researcher's computation, 2014

Table 6.2.7 Flooding in Ogolonto has destroyed several lives and properties

\begin{tabular}{|l|r|r|}
\hline & Frequency & Percent \\
\hline Very Highly Agree & 89 & 74.5 \\
Highly Agree & 9 & 7.5 \\
Very Highly Disagree & 8 & 6.7 \\
Highly Disagree & 11 & 9.2 \\
Undecided & 3 & 2.5 \\
Total & 120 & 100.0 \\
\hline
\end{tabular}

Source: Field Survey, March2014

Table 6.2.7 shows that, $89(74.5 \%)$ of the respondents 'very highly agree' that flood in Ogolonto has destroyed several lives and properties, $9(7.5 \%)$ 'highly agree', $8(6.7 \%)$ 'very highly disagree', $11(9.2 \%)$ 'highly disagree' and $3(2.5 \%)$ were undecided.

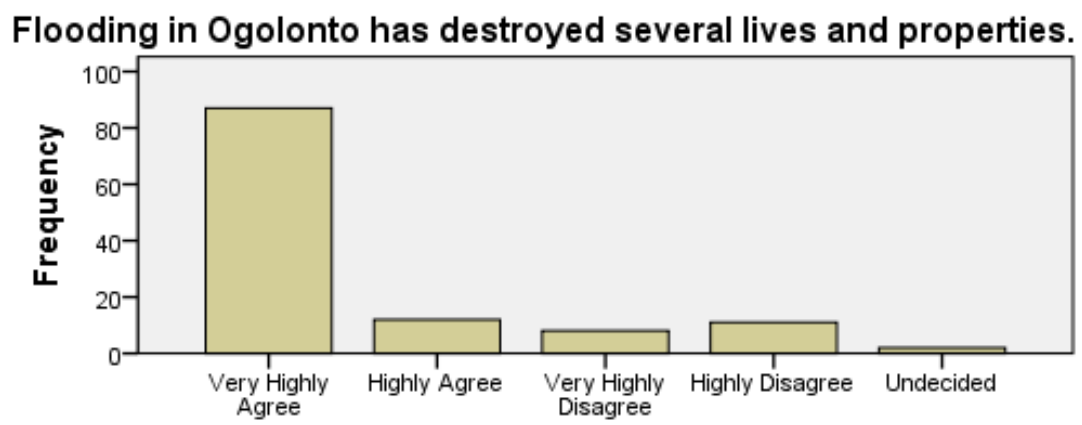
Flooding in Ogolonto has destroyed several lives and
properties.

Source: SPSS 21 Analysis, Researcher's computation, 2014 
Omologede Community Development Association and Flood Management in Ogolonto Community,

Table 6.2.8 The government is always on top of the situation as regards flood management in Ogolonto community

\begin{tabular}{|l|r|r|}
\hline & Frequency & Percent \\
\hline Very Highly Agree & 45 & 37.5 \\
Highly Agree & 19 & 15.8 \\
Very Highly Disagree & 36 & 30 \\
Highly Disagree & 11 & 9.2 \\
Undecided & 9 & 7.5 \\
Total & 120 & 100.0 \\
\hline
\end{tabular}

Source: Field Survey, March2014

Table 6.2 .8 shows, $45(37.5 \%)$ of the respondents 'very highly agree' that the government is always on top of the situation as regards flood management in Ogolonto community, 19(15.8\%) ' 'highly agree', 36(30\%) 'very highly disagree', 11(9.2\%) 'highly disagree' and 9(7.5\%) were undecided.

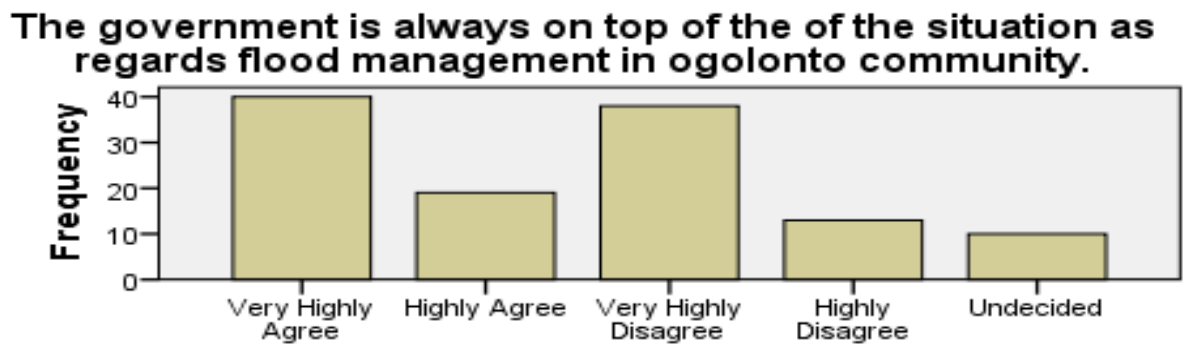

The government is always on top of the of the

Source: SPSS 21 Analysis, Researcher's computation, 2014

Table 6.2.9 Indigenes of Ogolonto observe environmental hygiene

\begin{tabular}{|l|r|r|}
\hline & Frequency & Percent \\
\hline Very Highly Agree & 69 & 57.5 \\
Highly Agree & 19 & 15.8 \\
Very Highly Disagree & 5 & 4.2 \\
Highly Disagree & 17 & 14.5 \\
Undecided & 10 & 8.3 \\
Total & 120 & 100.0 \\
\hline
\end{tabular}

Source: Field Survey, March2014

Table 6.2.9 shows that, $79(57.5 \%)$ of the respondents 'very highly agree' that the indigenes of Ogolonto community observe environmental hygiene, $19(15.8 \%)$ 'highly agree', $5(4.2 \%)$ 'very highly disagree', $17(14.5 \%)$ 'highly disagree' and10(8.3\%) were undecided.

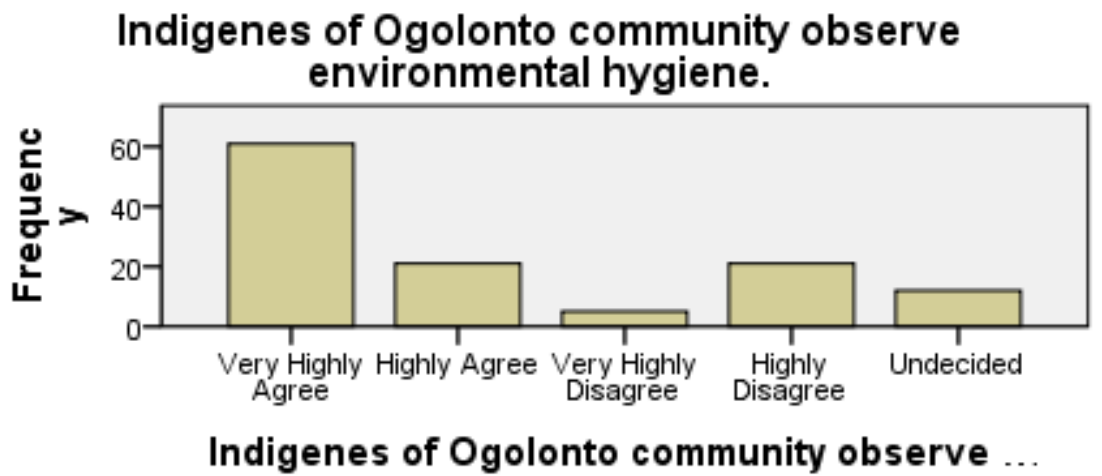

Source: SPSS 21 Analysis, Researcher's computation, 2014 
Omologede Community Development Association and Flood Management in Ogolonto Community,

Table 6.2.10 Ogolonto community indigenes contributes physically and financially to flood management in the area

\begin{tabular}{|l|r|r|}
\hline & Frequency & Percent \\
\hline Very Highly Agree & 67 & 55.8 \\
Highly Agree & 23 & 19.2 \\
Very Highly Disagree & 25 & 20.8 \\
Highly Disagree & 1 & 0.8 \\
Undecided & 4 & 3.3 \\
Total & 120 & 100.0 \\
\hline
\end{tabular}

Source: Field Survey, March2014

From table 6.2 .10 above, $67(55.8 \%$ ) of the respondents 'very highly agree' that the Ogolonto community indigenes contribute physically and financially to flood management in the area, 23(19.2\%) 'highly agree', 25 (20.8\%) 'very highly disagree', 1 (0.8\%) 'highly disagree' and 4(3.3\%) were undecided.

\section{Ogolonto community indigenes contribute physically and financially to flood management in the area.}

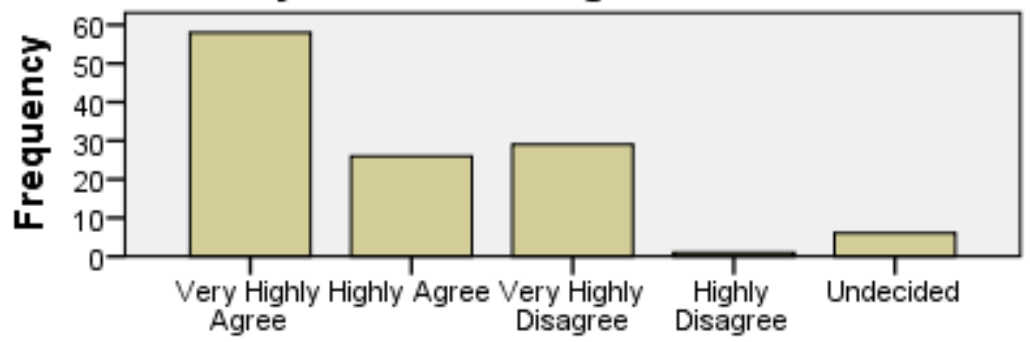

Ogolonto community indigenes contribute ...

Source: SPSS 21 Analysis, Researcher's computation, 2014

Table 6.2.11 Omologede CDA dose a lot to sensitize the community on flood management

\begin{tabular}{|l|r|r|}
\hline & Frequency & \multicolumn{2}{|c|}{ Percent } \\
\hline Very Highly Agree & 90 & 75.0 \\
Highly Agree & 21 & 17.5 \\
Very Highly Disagree & 6 & 5 \\
Highly Disagree & 3 & 2.5 \\
Total & 120 & 100.0 \\
\hline
\end{tabular}

Source: Field Survey, March2014

From table 6.2 .11 above, $90(75.0 \%)$ of the respondents 'very highly agree' that the Omologede Community Development Association does a lot to sensitize the community on flood management, 21(17.5\%) 'highly agree', 6 (5\%) 'highly disagree' and 3 (2.5\%) were undecided.

\section{Omologede CDA does a lot to sensitize the community on flood management.}

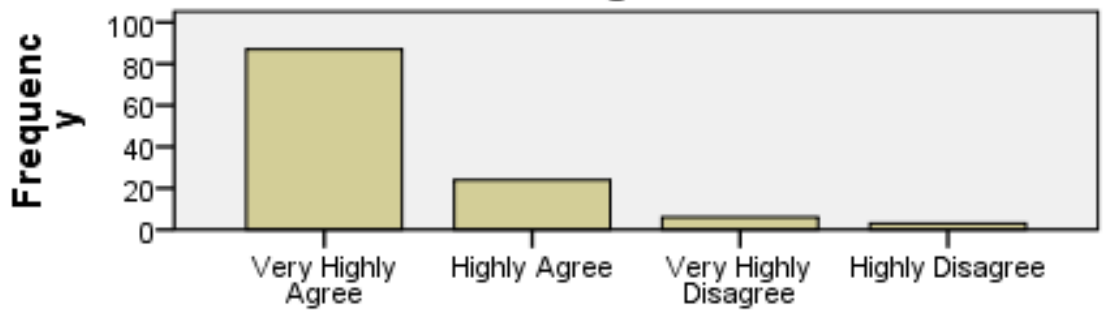

Omologede CDA does a lot to sensitize the ...

Source: SPSS 21 Analysis, Researcher's computation, 2014 
Omologede Community Development Association and Flood Management in Ogolonto Community,

Table 6.2.12 Omologede CDA has helped in building drainage system to control flood

\begin{tabular}{|l|r|r|}
\hline & Frequency & Percent \\
\hline Very Highly Agree & 90 & 75 \\
Highly Agree & 7 & 5.8 \\
Very Highly Disagree & 12 & 10 \\
Highly Disagree & 6 & 5 \\
Undecided & 5 & 4.7 \\
Total & 120 & 100.0 \\
\hline
\end{tabular}

Source: Field Survey, March2014

From table 6.2.12 above, 90(75\%) of the respondents chose 'very highly agree' that the Omologede Community Development Association has helped in building drainage system to control flood, 7 (5.8\%) 'highly agree', 12 (10.7\%) 'very highly disagree', 6 (5\%) 'highly disagree' and 5 (4.7\%) were undecided.

\section{Omologede CDA has helped in building drainage system to} control flood.

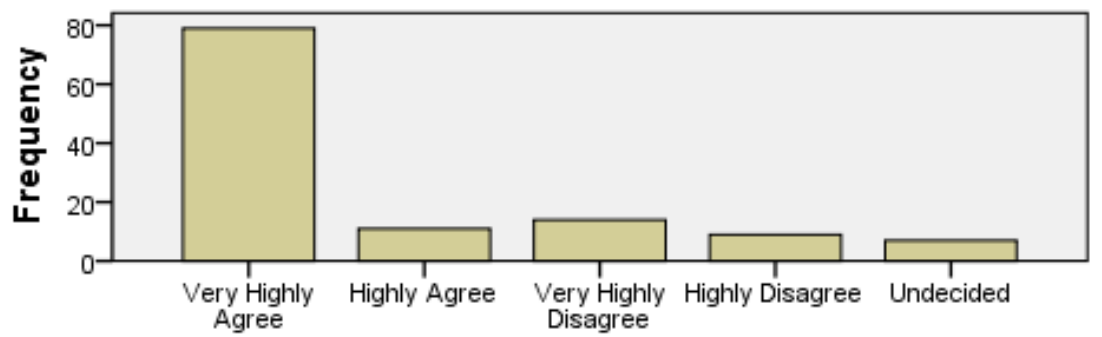

Omologede CDA has helped in building drainage syst...

Source: SPSS 21 Analysis, Researcher's computation, 2014

Table 6.2.13 There is a robust partnership between the indigene's of Ogolonto and Omologede CDA in managing flood in the area

\begin{tabular}{|l|r|r|}
\hline & Frequency & Percent \\
\hline Very Highly Agree & 72 & 60 \\
Highly Agree & 20 & 16.7 \\
Very Highly Disagree & 16 & 13.3 \\
Highly Disagree & 9 & 7.5 \\
Undecided & 3 & 2.5 \\
Total & 120 & 100.0 \\
\hline
\end{tabular}

Source: Field Survey, March2014

From table 6.2 .13 above, $72(60 \%)$ of the respondents chose 'very highly agree' that there is a robust partnership between the indigene's of Ogolonto and Omologede community development association in managing flood in the area, 20 (16.7\%) 'highly agree', $16(13.3 \%)$ 'very highly disagree', $9(7.5 \%)$ 'highly disagree' and $3(2.5 \%)$ were undecided.

\section{There is a robust partnership between the indigence's of Ogolonto and Omologede CDA in managing flood in the area}

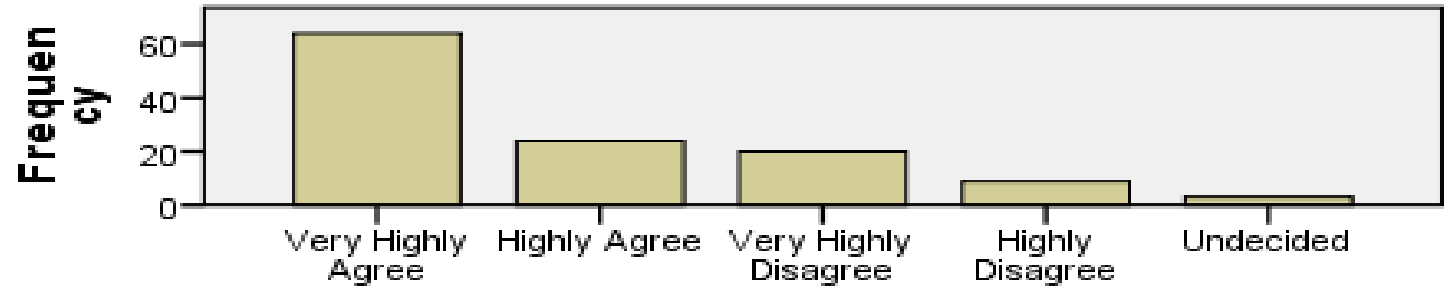

There is a robust partnership between the ...

Source: SPSS 21 Analysis, Researcher's computation, 2014 
Omologede Community Development Association and Flood Management in Ogolonto Community,

Table 6.2.14 Omologede CDA partners with NGOs on flood management strategies

\begin{tabular}{|l|r|r|}
\hline & Frequency & Percent \\
\hline Very Highly Agree & 74 & 61.7 \\
Highly Agree & 21 & 17.5 \\
Very Highly Disagree & 7 & 5.3 \\
Highly Disagree & 15 & 12.5 \\
Undecided & 3 & 2.5 \\
Total & 120 & 100.0 \\
\hline
\end{tabular}

Source: Field Survey, March2014

From table 6.2.14 above, 74 (61.7\%) of the respondents chose 'very highly agree' that the Omologede Community Development Association often partner with NGOs on flood management strategies, 21(17.5\%) 'highly agree', 7 (5.3\%) 'very highly disagree', 15 (12.5\%) 'highly disagree' and 3(2.5\%) were undecided.

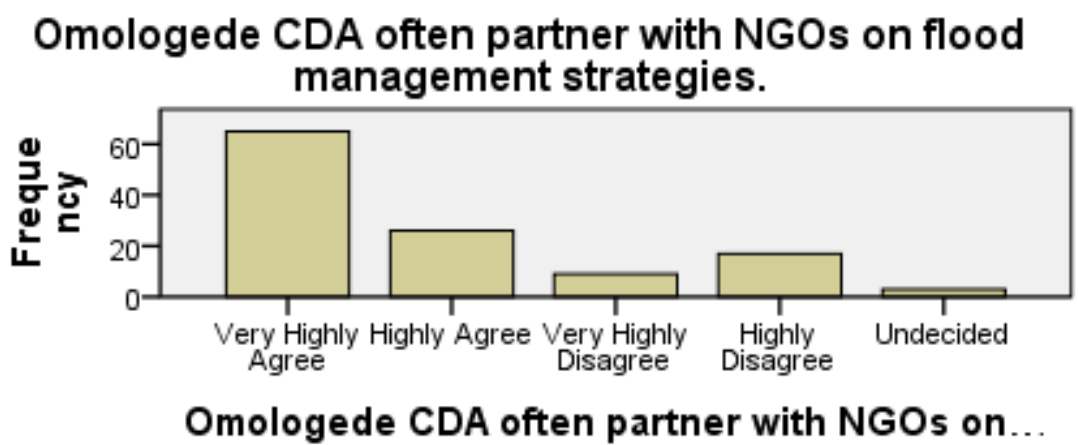

Source: SPSS 21 Analysis, Researcher's computation, 2014

The respondents also mentioned that the Omologede CDA has assisted in flood management in the community in the following ways;

A. Partnering with Senator Gbenga Ashafa in putting up a drainage system for easy flow of water.

B. Involving the community members in channeling the drainage through direct labour.

C. Embarking on fund raising efforts.

D. Encouraging members of the community to regularly clear the drainages for free flow of water.

E. Writing letters to the government for support.

F. Contributing funds towards construction of bridges and roads in the area.

\section{Summary Of Findings}

From the study, Omologede Community Development Association has highly helped in the reduction of flood in Ogolonto community. This is evident in the fact that $60 \%$ of the respondent agreed to all the questions asked on the questionnaire which indicated that they are satisfied with the efforts the Community Development Association is putting into flood management; $70 \%$ of the respondent agreed that Omologede Community Development Association is a well-known association among indigenes of Ogolonto community; $55.8 \%$ of the respondent agreed that Omologede Community Development Association advocate the interest of the people before the government; $71.7 \%$ of the respondent agreed that flood is a development challenge in Ogolonto community; $37.5 \%$ of the respondent agreed that the government in always on top of the situation as regards flood management in Ogolonto community. Although a large amount of people agreed to the fact that government is assisting in flood management; $30 \%$ of the respondent disagree to the fact that the government are assisting in flood management in Ogolonto area of Ikorodu.

\section{Conclusion}

This study reveals that flood is a major problem in Ogolonto community and it has affected mainly in the aspect of loss of property and has also made people migrate from their environment. However, Omologede Community Development Association has made a great impact in the management of flood and flood disasters in the community. The building of drainage systems and several fund raising efforts of the association go to show that community development associations are relevant to the development of rural communities, especially as regards flooding.

Governments, especially at the state levels should endeavor to be more involved in the development efforts of rural communities within the state, as these efforts can become wearisome if entirely left to the 
communities and community development associations. It is also important that government recognize more the efforts of community development associations and empower them to be more productive in the communities.

\section{References}

[1]. Abegunde, .A. A .(2004). Community based organizations in sustainable development of Rural areas of Atiba L.G.A, Oyo State, Journal of the Nigerian Institute of Town Planners (NITP), 17(1), 19.

[2]. Adedeji, A. A. and Salami .A. W. (2008). Environmental hazard: Flooding and Its Effects on Residential Buildings in Ilorin, Nigeria.

[3]. Adetunji, A.M. (2006). Flood in Nigeria, Lagos, National Open University of Nigeria, The Regent Ltd.

[4]. Afigbo, A E; Aja A. and Emeribe A C (2000). Towards understanding community Development Through self-help The Nigerian example. In Policy and contending Issues in Nigeria's National Development strategy, John Jacob's Classic Publishers Limited, Enugu.

[5]. Akinsorotan, A.O. and Olujide, M.G. (2006), Community Development Associations' Contributions in Self Help Projects in Lagos State of Nigeria, Journal of Central European Agriculture, Volume 7 (2006) No. 4 (609-618)

[6]. Amadike, P.C. (1989), Community Development: A Strategy for National Development National Seminar on Community Development Programmes, University of Ibadan .pp15

[7]. Emodi E.E. (2012). The Menace of Flood in Nigeria: Impacts and Rehabilitation Strategies Journal of Environmental Management and Safety.

[8]. Field Survey on Omologede Community Development Association, March 2014

[9]. Fukuyama, F. (1999). Social capital and civil society conference paper prepared for the International Monetary Fund (IMF). Available online: <http://internationalmonetaryfund.com/external/pubs/ft/seminar/1999/reforms

[10]. Musa, S. D. (2005). Sustainable grassroots development: A major challenge of globalization. In A. D., The humanities and globalization - The African perspective (pp. 252-260). Makurdi: Aboki Publishers.

[11]. Odufuwa B.O; Adedeji O.H; Oladesu J. O. \& Bongwa A. (2012). Flood Of Fury in Nigerian Cities Journal of Sustainable Development; Vol. 5, No. 7.

[12]. Okafor, S. I. (2002). Indigenous institution and sustainable development initiatives in S.I. Journal of Administration Overseas, $16(2), 114-120$.

[13]. Oyebande, L. (1975). Water resource problems in Africa. In Richards, P.African Environmental problems and perspectives London. International African Institute

[14]. Peterman, W. (2000). Neighborhood planning and community-based development - The potential and limits of grassroots action, California: Sage Publications Inc.

[15]. Punch newspaper, Oct 242012 Devastating effect of flood. 